\title{
ALGUNS EXEMPLOS DO POTENCIAL DA BIOGEOGRAFIA MARINHA COMO INSTRUMENTO DE ANALISE DE MUDANÇAS PROGRESSIVAS NO LITORAL BRASILEIRO
}

\section{Eurico Cabral de 01 iveira?}

E fato notório que a distribuicão dos organismos nos ambientes marinhos, tanto quanto nos terrestres, se verifica na forma de arranjos mais ou menos discretos, os quais são condicionados por um conjunto de fatores ambientais e interações bióticas.

Embora os parâmetros abióticos marinhos variem em amplitudes atenuadas em relação aos ambientes emersos, particularmente no que diz respeito à temperatura, mesmo assim atribui-se a este fator um papel primordial no controle das comunidades marinhas. Paralelamente pode-se acrescentar como fatores condicionantes dos padrões de distribuição as variações de salinidade, nutrientes e penetração de luz.

Nesta comunicaça daremos alguns exemplos que mostram como organismos marinhos estacionários podem ser usados como sensores adequados para se inferir condições ambientais pretéritas e permitir prognósticos sobre a evolução de ecossistemas litorâneos.

A. Alterações naturais em tempo geológico.

1. Laminaria, gênero de algas pardas caracteristico das águas frias do hemisfério norte, apresenta duas espécies endêmicas ao litoral capixaba e norte fluminense (1), (2).

1 Instituto de Biociências e Centro de Biologia Marinha - USP 
Uma terceira espécie é encontrada nas águas frias da Africa do Sul e Namibia.

No hemisfério norte as espécies mais abundantes marcam a zona das marés baixas, chegando a ficarem expostas ao ar nas mares de sizigia. As espécies brasileiras nunca foram coletadas em profundidades menores que $40 \mathrm{~m}$, sendo abundantes a até $100 \mathrm{~m}$ de profundidade.

Acreditamos que o banco de Laminárias brasileiras viva em uma corrente de águas frias que se desloca para o norte por baixo das águas quentes da Corrente do Brasil. No entanto, os dados de temperatura que dispomos são fragmentários e contraditórios (3).

Experimentos realizados in vitro mostram que os gametófitos das espécies brasileiras não toleram exposiçoes prolongadas a temperaturas superiores a $16^{\circ} \mathrm{C}(4)$, e que são interférteis com espécies do Atlântico Norte (Alemanha), evidência de uma origem comum (5).

Assim, os dados existentes permitem supor que as espécies brasileiras migraram do hemisfério norte em um passado em que as águas que banham as costas tropicais do Brasil eram consideravelmente mais frias. Interpretamos as populaçoses atuais das costas brasileiras como relictos de uma distribuiça mais ampla e de águas mais rasas.

2. A fauna e a flora das águas tropicais brasileiras apresentam uma grande afinidade com as do Caribe. Nesta região são encontrados 4 gêneros de angiospermas marinhas submersas. No Brasil ocorrem apenas dois gêneros (Halodule e Halophila) (6). Acreditamos que os demais gêneros do Caribe, não encontrados no Brasil, devem ter migrado para o Caribe após o Rio Amazonas, hoje uma formidável barreira para a dispersão de organismos marinhos bentônicos, ter atingido niveis consideráveis de aporte de água doce e sedimentos.

3. Uma ampla faixa da plataforma continental brasileira ao norte do Cabo Frio (RJ) apresenta extensos depósitos de algas 
calcárias macroscópicas bentônicas estimados em cerca de 200 bilhões de toneladas (7). Estas algas apresentam um teor de $\mathrm{CaCO}_{3}$ que chega a $95 \%(8)$. Estes espessos depósitos, em sua maior parte recobertos por uma delgada camada de poucos centimetros de algas vivas, constituem um imenso reservatório de carbono e ilustram bem a importância da fotossintese na imobilização de um eventual excesso de $\mathrm{CO}_{2}$ atmosférico em equilibrio com $\mathrm{O}_{2}$ dissolvido na água do mar.

4. Em muitos trechos da costa brasileira são abundantes as marcas deixadas por uma especie de ouriço-do-mar, Echinometra lucunter, em costões rochosos em niveis muito superiores ao atual nivel do mar. Em se tratando de uma espécie que não tolera periodos prolongados de exposiça ao ar, estas marcas indicam niveis mais altos do mar ou soerguimentos da borda da plataforma continental em épocas pretéritas.

B. Alterações de origem antrópica.

1. Episódicas (agudas) - acidentes com derramamento de petróleo passaram a ser uma rotina no litoral norte do Estado de São Paulo, nas vizinhanças de São Sebastião. Embora não existam dados coletados sistematicamente na região, estes "acidentes" possivelmente poderão levar a modificações previsiveis da biota local, com consequências de ordens diversas, inclusive econômicas.

2. Cumulativas (crônicas) - alterações substanciais da flora marinha foram detectadas no espaço de duas décadas na baía de Santos (SP), consequentes do crescimento do complexo portuário e urbano em desenvolvimento na região (9). Um melhor entendimento destas transformações permitirá a elaboração de modelos para se prever o destino de outras áreas em desenvolvimento no litoral brasileiro.

os exemplos mencionados acima, baseados unicamente em observações biológicas, necessitam de uma abordagem 
multidisciplinar para se obter um conhecimento mais abrangente de suas causas que nos permita fazer prognósticos confiáveis para um futuro em diferentes escalas de tempo.

REFERENCIAS BIBLIOGRAFICAS

(1) JOLy, A.B. \& OLIVeira, E.C. (1967) Inst. Pesq. Marinha, 4:1-13.

(2) Oliveira, E.C. \& Quege, N. (1978) Inst. Pes. Tec., Pesq. Desenv., São Paulo, 1:1-18

(3) QUEGE, N. (1988) Laminaria (Phaeophyta) no Brasil - Uma perspectiva econômica. Dissert. de Mestrado, Inst. Biociências, Univ. São Paulo.

(4) OLIVEIRA, E.C. (1987) Neritica 2 (sup1.):153-148.

(5) DiECK, I.T. \& OLIVEIRA E.C. (Comunicação pessoal).

(6) OLIVEIRA, E.C. et a 1. (1983) Aquatic Botany, 16:251-267.

(7) Milliman, J.D. \& AMARAl, C.A. (1974) B. Soc. Bras. Geol., Anais, 27., Congr. Porto Alegre, 335-344

(8) MONT'ALVERne, A.A.F. (1982) Estudo dos calcários na plataforma continental de Pernambuco. Dissert. Mestrado, Univ. Fed. Pernambuco, Recife.

(9) Oliveira, E.C. \& Berchez, F.A.S. (1978) Bol. Botânica, Univ. São Paulo, 6:49-59. 